\title{
ECHOVIRUS 4 ASSOCIATED TO HAND, FOOT AND MOUTH DISEASE
}

\begin{abstract}
SUMMARY
Hand, foot and mouth disease (HFMD) is a contagious enteroviral infection occurring primarily in children and characterized by vesicular palmoplantar eruptions and erosive stomatitis. Echovirus 4 (EV-4) has been commonly associated with aseptic meningitis. The association of HFMD with EV-4 has not been reported previously. Two samples of a 14-month child who presented mild fever, sores in the mouth, rash with blisters on the palm of hands and soles of feet were sent to Enteric Viruses Laboratory of Adolfo Lutz Institute. Clinical samples were inoculated in three different cell lines, and those which presented cytopathic effect (CPE), were submitted to Indirect Immunofluorescence Assay (IFA) and "one step" RT-PCR. Agarose gel electrophoresis from RT-PCR product, showed a product with $437 \mathrm{bp}$, which is characteristic of Enterovirus group. Echovirus 4 was identified by IFA. Although HFMD is a viral infection associated mainly with Enterovirus 71 (HEV-71) and Coxsackievirus A16 (CV-A16), our results demonstrate a diversity of serotype related to HFMD and stress the importance of epidemiological surveillance to this disease and its complications.
\end{abstract}

KEYWORDS: Hand, foot and mouth disease; Enterovirus; Echovirus.

\section{INTRODUCTION}

Hand, Foot and Mouth Disease (HFMD) is a common illness of infants and children under 10 years old and is characterized by fever, sores in mouth and rash with blisters. HFMD begins with a mild fever, poor appetite, malaise and frequently sore throat. One or two days after, fever and the development of sores in the mouth are observed. Small red spots with blister that become ulcers commonly appear. They are usually located on the tongue, gums and inside the cheeks. The skin rash develops over 1-2 days with flat or raised red spots, and some with blisters. The rash does not itch and is usually located on the palms of the hand and soles of the feet. It also appears on the buttocks. Although, some person with HFMD may have only rash or mouth ulcers $^{4}$

Transmission occurs from person to person by direct contact with nose and throat discharges or by faecal oral routes. HFMD is not transmitted to or from pets or other animals. Individual cases of HFMD occur worldwide, more frequently in summer and early autumn ${ }^{4}$. Vertical spread from mother to fetus also occurs but, cases resolve with no long-term complications, first trimester infection may lead to spontaneous abortion or intrauterine growth retardation. Other complications have been reported including myocarditis, meningoencephalitis, pulmonary edema and even death ${ }^{16}$.

The first HFMD report was done by ROBINSON \& RHODES in $1958^{12}$. They reported an exanthem with associated fever and oral lesions, noted in over 60 persons in June and July 1957 in Toronto, Canada. Coxsackievirus A16 (CV-A16) was isolated from two-thirds of 27 stool specimens studied. The next reported epidemic of Coxsackievirus occurred in Birmingham, England, in the summertime of 1960 and was described by ALSOP et al. ${ }^{2}$ who noted vesicular lesions on the hands and feet with oropharyngeal lesions and who named the eruption hand, foot and mouth disease ${ }^{16}$.

HFMD is caused by Enteroviruses, members of the Picornavirus family (single-stranded RNA, non enveloped) and is most commonly associated with CV-A16 or Enterovirus 71 (HEV-71). Sporadic cases associated with CV-A4 to CV-A7, CV-A9, CV-A10, CV-B1 to CV-B3 and CV-B5 have also been reported. Infections are usually sporadic but epidemics do regularly occur. Initial viral infection is the buccal mucosa and ileal mucosa and is followed by spread to regional lymph nodes within 24 hours. Viremia rapidly follows and virus spreads to oral mucosa and skin. About the $7^{\text {th }}$ day after infection, serum antibody levels may start to increase ${ }^{6,8}$.

\section{PATIENTS AND METHODS}

Samples: During July 2003 a HFMD outbreak occurred in a day care center in São Paulo City, and two stool samples of a 14-month male child suspected case were sent to Enteric Viruses Laboratory of Adolfo Lutz Institute. He presented fever, sores in the mouth, malaise, poor appetite and rash on the palms and feet soles. Other eight children of the same center, in a range from 10 months to three years old, 
presented similar symptoms. HFMD was diagnosed by other medical centers (Personal communication). It was impossible to collect paired serum samples to proceed the serological tests to antibody titration.

Viral isolation and identification: Samples collected within six days of lap, were clarified under centrifugation at 10,000 x g/60 minutes, at $4{ }^{\circ} \mathrm{C}$; antibiotics (streptomycin and penicillin [50 mg]) were added and the supernatant was stored at $-70^{\circ} \mathrm{C}$ until inoculation $(0.1$ and 0.2 $\mathrm{mL} /$ tube) on three different cell lines: RD (human rhabdomyosarcoma), HEp 2 (human larynx carcinoma epidermal) and Vero (green monkey kidney) containing minimal essential medium (Eagle's L15, Eagle's + AANE + piruvate, and 199 medium, respectively). After, the tubes were kept at $35-37{ }^{\circ} \mathrm{C}$. The cultures were observed at inverted microscope every day, in order to visualize cytopathic effect (CPE). Successive passages of the inoculated material were made until the appearance or not of characteristic CPE of HEV infection? ${ }^{7}$

Indirect Immunofluorescence Assay - IFA: When the cell culture presented at least $75 \%$ of CPE, it was scraped off the tube and the cell suspension was spotted onto a glass slide, which were air dried and fixed with acetone. Then, it was submitted to Indirect Immunofluorescence Assay (IFA), using specific monoclonal antibodies, commercially available (Chemicon International Inc., Temecula, CA/USA) to genus, group and HEV serotypes. The slide wells were examined under an epifluorescence microscope ${ }^{3}$.

RT-PCR: The viral RNA was extracted from isolate virus by Trizol ${ }^{\circledR}$ LS (Invitrogen, cat. 1296-010) and chloroform, according to the manufacturer's instruction. Following centrifugation at $12,000 \mathrm{xg}$, the aqueous phase was separated and the precipitation done with isopropyl alcohol. The RNA pellet was washed with $75 \%$ ethanol. At the end of procedure, the RNA was dried briefly and resuspended with Milli-Q water; RNAsin [10U] as added and the RNA stored at $-70{ }^{\circ} \mathrm{C}$. The cDNA was synthesized using the extracted RNA and the mixture: 50 $\mathrm{mM} \mathrm{MgCl}$; 10x PCR buffer; $1.25 \mathrm{nM}$ dNTP; $20 \mu \mathrm{M} / \mu \mathrm{L}$ primer AS1/ S1; $2 \mu \mathrm{L}$ Super Script II RNAse Reverse Transcriptase; $2.5 \mathrm{U} / \mu \mathrm{L}$ TaqQ DNA Polymerase; $40 \mathrm{U} / \mu \mathrm{L}$ RNAsin [10U] and Milli-Q water. The amplification reactions were carried out in Gene Amp PCR System 9600 Perkin Elmer thermocycler with the following programming: $\left(42^{\circ} \mathrm{C} / 1 \mathrm{~h}\right)+\left(95^{\circ} \mathrm{C} / 5 \mathrm{~min}\right)+25$ cycles $\left(94^{\circ} \mathrm{C} / 1 \mathrm{~min}+50^{\circ} \mathrm{C} / 2 \mathrm{~min}+\right.$ $\left.72{ }^{\circ} \mathrm{C} / 1 \mathrm{~min}\right)+\left(72^{\circ} \mathrm{C} / 7 \mathrm{~min}\right)$. PCR products were separated by $1.5 \%$ agarose gel, stained with ethidium bromide, and visualized under UV light. The primers directed to 5'non-translated region amplified a product of $437 \mathrm{bp}^{13}$.

\section{RESULTS}

CPE suggestive of HEV: rounding, shrinking, nuclear pyknosis, refractility, and cell degeneration were sensitive to RD and Vero cells. The time to reporting positive cultures was about 4-7 days.

A bright apple-green fluorescence in the nucleous and/or cytoplasma of cells could be observed under the epifluorescence microscope, at $400 \mathrm{x}$, indicating a positive reaction to echovirus 4 serotype. IFA was negative to the other monoclonal antibodies.

RT-PCR was applied to confirm the HEV genus. Agarose gel electrophoresis showed a product with 437 bp, identifying HEV (Fig. 1).

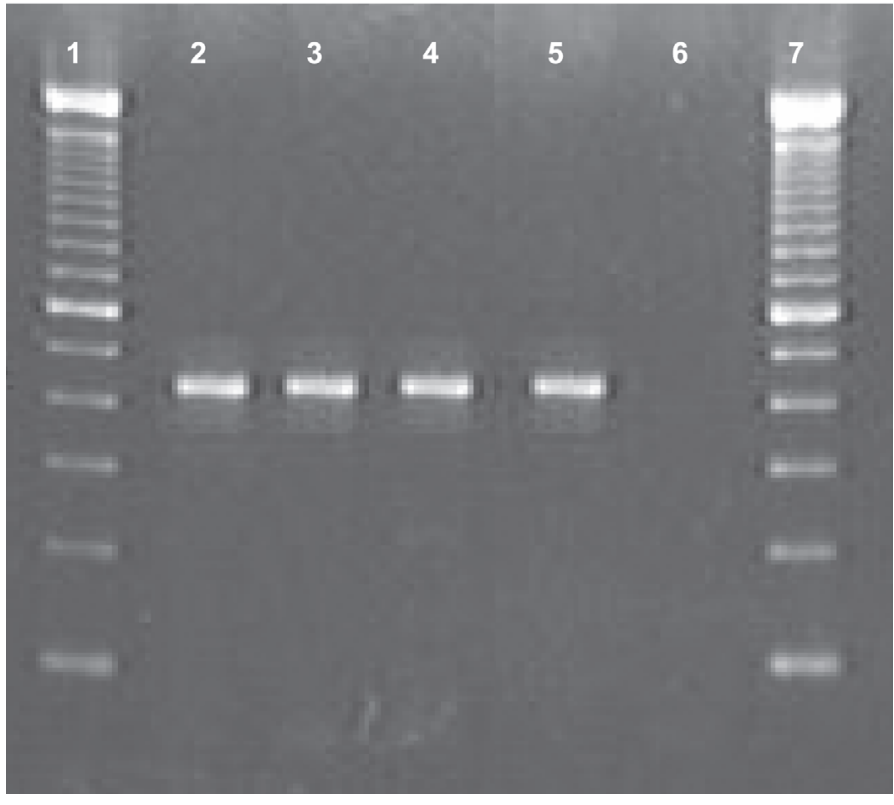

Fig. 1 - RT-PCR to the 5'NCR region of the Enterovirus isolated in cell culture. Lane 1 and 7: molecular weight (MW) $100 \mathrm{bp}$. Lanes 2, 3, 4 and 5: amplification product of $437 \mathrm{bp}$. Lane 6: negative control.

\section{DISCUSSION}

The etiologic agent identified in this study is HEV different from the other previously related to HFMD. This syndrome has commonly been associated with CV-A16 and HEV-71 while none epidemiological data about EV-4 associated to HFMD, was found in the literature.

Meanwhile the HFMD outbreak occurred in Malaysia (1997) was associated to EV-1, CV-A9 and HEV-71 ${ }^{1}$. HFMD caused by HEV-71 has been associated with fatal cases of encephalitis during the outbreaks in Malaysia (1997) and Taiwan (1998) ${ }^{17}$. EV-7 was found during the latter part of 2000, in addition to CV-A16 and EV-7, as a HFMD aetiologic agent ${ }^{5}$. In Brazil, MOREIRA et al., (1995) related an epidemic exanthematic disease associated with coxsackievirus B3 (CVB 3$)^{10}$. No report about the association with EV-4 and HFMD is related in Brazil, maybe due to the lack of clinical suspicions.

The EV-4 is generally related with aseptic meningitis, encephalitis, paralysis, Güillan-Barré syndrome, exanthem and respiratory diseases and has been found around the world, mainly as the cause of aseptic meningitis outbreaks: in Cuba, from 1972 to 1999; in Cape Town, South Africa from 1981 to 1989; April 1997 in regions of Israel and the Palestinian Authority; in Spain during 1988 to 2003; autumn 1982 in Poland, and in Vellore and surrounding areas in India in 2002 $2,9,11,14,15,18$.

Typically, enterovirus infections are either asymptomatic or result in mild disease. So, it is recommended to collect serum samples to proceed antibody titration by microneutralization technique, what would be one more parameter to confirm that the virus isolated is the responsible for the disease. Associated with the stool isolation, the increase of fourfold of serum titration (seroconversion) confirms the acute infection. Unfortunately, serum samples were not possible to obtain in this study. 
In spite of, all of other eight children were diagnosed as HFMD by medical centers, based on the clinical signs.

Although this result could be not enough to state that EV-4 was a cause of disease, it seemed reasonable to conclude that signals and evident clinical manifestations confirm the hypothesis that virus is not a passing virus.

It is important to accentuate that CV-A16 and HEV-71, known as the main cause of HFMD, usually produce CPE in RD, HEp2 and Vero cell cultures; but in this study they were not identified.

Our work shows EV-4 as a causal agent of HFMD and suggests the possibility that other HEV serotypes, could be eventually related to HFMD cases. This case report emphasizes the necessity to intensify epidemiological and laboratorial studies on this serotype and the surveillance for other HEV serotypes involved in HFMD, must be increased in Brazil.

\section{RESUMO}

\section{Echovirus 4 associado à doença de mão, pé e boca}

A Doença de Mão, Pé e Boca (DMPB) é uma infecção enteroviral contagiosa que ocorre principalmente em crianças sendo caracterizada por erupções palmoplantares vesiculares e estomatite. Echovirus 4 (EV4) é comumente associado a meningite asséptica. A associação de DMPB por EV-4 não foi descrita anteriormente. Duas amostras provenientes de uma criança de 14 meses apresentando febre, secreções na garganta e exantemas nas palmas das mãos e dos pés, foram enviadas para o Laboratório de Vírus Entéricos do Instituto Adolfo Lutz. As amostras foram inoculadas em três diferentes linhagens celulares; aquelas que apresentaram efeito citopático (ECP), foram submetidas a ensaio de imunofluorescência indireta (IFI) e "one step" RT-PCR. A eletroforese em gel de agarose realizada com o produto de PCR apresentou um produto de $437 \mathrm{pb}$, característico de grupo Enterovirus. O sorotipo EV-4 foi identificado por IFI. Apesar da DMPB ser uma infecção viral associada principalmente com Enterovirus 71 (HEV71) e Coxsackievirus A16 (CV-A16), nossos resultados enfatizam a necessidade de estudos epidemiológicos e laboratoriais direcionados ao EV-4 como agente causador de DMPB.

\section{ACKNOWLEDGEMENTS}

We are specially grateful to Dr. Luís Florêncio Salles Gomes for his suggestions and criticisms on this paper.

\section{REFERENCES}

1. ABUBAKAR, S.; CHEE, H.Y.; SHAFEE, N.; CHUA, K.B. \& LAM, S.K. - Molecular detection of Enteroviruses from an outbreak of hand, foot and mouth disease in Malaysia in 1997. Scand. J. infect. Dis., 31: 331-335, 1999.

2. ALSOP, J.; FLEWETT, T.H. \& FOSTER, J.R. - "Hand-foot-and-mouth disease" in Birmingham in 1959. Brit. med. J., 5214: 1708-1711, 1960.
3. BASTIS, D.; SIMONET, S.; PATTERSON, M.A. \& NEILL, S. - Identifications of Enteroviruses by indirect immunofluorescence using monoclonal antibodies. Clin. diagn. Virol., 3: 38-93, 1995.

4. CENTERS FOR DISEASE CONTROL AND PREVENTION - Respiratory and Enteric Viruses Branch, 2004. (available in http://www.cdc.gov/ncidod/dvrd/revb/ Enterovirus/hfhf.htm). Accessed in May, 2005.

5. CHUA, B.H.; McMINN, P.C.; LAM, S.K. \& CHUA, K.B. - Comparison of the complete nucleotide sequences of echovirus 7 strain UMMC and the prototype (Wallace) strain demonstrates significant genetic drift over time. J. gen. Virol., 82: 2629-2639, 2001.

6. GRAHAM, B. - Hand, foot and mouth disease. EMedicine Journal, 2002. (available in http://www.emedicine.com/derm/topic175htm). Accessed in May, 2005.

7. GRANDIEN, M.; FORSGREN, M. \& EHRNST, A. - Enteroviruses and reoviruses. In: LENNETTE, E.H. \& SCHMIDT, N.J., ed. Diagnostic procedures for viral and rickettsial diseases. 6. ed. Washington, American Public Health Association, 1989. p. 513-578.

8. HANDSHER, R.; SHULMAN, L.M.; ABRAMOVITZ, B. et al. - A new variant of echovirus 4 associated with a large outbreak of aseptic meningitis. J. clin. Virol., 13: 29-36, 1999.

9. McINTYRE J.P. \& KEEN, G.A. - Laboratory surveillance of viral meningitis by examination of cerebrospinal fluid in Cape Town 1981-9. Epidem. Infect., 111: 357-371,1993.

10. MOREIRA, R.C.; CASTRIGNANO, S.B.; CARMONA, R.C. et al. - An exanthematic disease epidemic associated with coxsackievirus B3 infection in a day care center. Rev. Inst. Med. trop. S. Paulo, 37: 235-238, 1995.

11. PIERZCHALA, K.; GRUDZINSKA, B.; BARA, M. \& KLOSINSKA, E. - Late sequelae of epidemic viral meningitis. Wiad. lek., 42: 55-158, 1989.

12. ROBINSON, C.R.; DOANE, F.W. \& RHODES, A.J. - Report of an outbreak of febrile illness with pharyngeal lesions and exanthem: Toronto, summer 1957; isolation of group A Coxsackie virus. Canad. med. Ass. J., 79: 615-621, 1958.

13. ROTBART, H.A. - Enzymatic RNA amplification of the enteroviruses. J. clin. Microbiol., 28: $438-442,1990$.

14. SARMIENTO, L.; MAS, P.; GOYENECHEA, A. et al. - First epidemic of echovirus 16 meningitis in Cuba. Emerg. infect. Dis., 7: 887-889, 2001.

15. SATHISH, N.; SCOTT, J.X.; SHAJI, R.V. et al. - An outbreak of echovirus meningitis in children. Indian Pediat., 41: 384-388, 2004.

16. SCOTT, L.A. \& STONE, M.S. - Viral exanthems. Derm. Online J., 9: 4, 2003.

17. SHIMIZU, H.; UTAMA, A.; YOSHII, K. et al. - Enterovirus 71 from fatal and nonfatal cases of hand, foot and mouth disease epidemics in Malaysia, Japan and Taiwan in 1997-1998. Jap. J. infect. Dis., 52: 12-15, 1999.

18. TRALLERO, G. \& AVELLÓN, A. - Importancia del diagnostico de los Echovirus desde el punto de vista epidemiológico. Circulación de Echovirus 11 en los últimos años en España - Control Calidad SEIMC, 2004. (available in http://seimc.org/control/ revi_viro/echo11.htm). Accessed in May, 2005

Received: 5 September 2005

Accepted: 27 April 2006 